\title{
Evaluation of the AIDS clinical trials group staging criteria for Kaposi Sarcoma in a resource limited setting
}

Fred Okuku ${ }^{1,2^{*}}$, Jackson Orem ${ }^{1,2}$, James Kafeero ${ }^{1}$, Warren Phipps ${ }^{3,7}$, Moses R Kamya ${ }^{2}$, Corey Casper $3,4,5,6,7$

From 13th International Conference on Malignancies in AIDS and Other Acquired Immunodeficiencies (ICMAOI)

Bethesda, MD, USA. 7-8 November 2011

\section{Background}

Kaposi sarcoma (KS) is commonly staged using by the AIDS Clinical Trials Group (ACTG) criteria. The three variables of the ACTG are dichotomized as good risk (0) and poor risk (1). Good risk immune status (I0) is defined as CD4 T-cell count $\geq 200$ cells $/ \mu$ l, and poor risk (I1) as CD4 < 200cells $/ \mu$ l. Although validated in the US and Europe, no evaluation has been done in resourcelimited settings during the HAART era. We sought to determine whether the ACTG staging criteria is predictive of overall survival among Ugandan patients with HIV-associated KS.

\section{Methods}

Data were abstracted from medical records of adult patients with HIV-associated KS seen at the Uganda Cancer Institute (UCI) from 2000-2006. The primary outcome was 2-year overall survival. Vital status at 2 years was determined from the medical chart, or by contacting the patient or next of kin using the phone contact provided in the chart or ART clinic. Survival was modeled using Kaplan-Meier methods. Factors associated with survival were evaluated using Cox proportional hazards.

\section{Results}

The median survival time was 468 days (range 0, 5411). At 2 years following KS diagnosis, 165 (40.8\%) of participants were alive and $166(41.1 \%)$ had died, while 73(18.1\%) were lost to follow-up. Factors associated with death before 2 years from KS diagnosis included T1 tumor stage, S1 stage, nodular lesion morphotype, and trunk edema (Table 1). Baseline CD4 count under 100 cells/ $\mu \mathrm{l}$ was associated with decreased survival (HR

Table 1 Factors associated with death before 2 years from KS diagnosis

\begin{tabular}{|c|c|c|c|c|c|c|}
\hline \multirow[b]{2}{*}{ FACTOR } & \multicolumn{3}{|c|}{ Univariate } & \multicolumn{3}{|c|}{ Multivariate } \\
\hline & HR & $95 \%$ & $\mathrm{Cl}$ P-value & HR & $95 \%$ & Cl P-value \\
\hline T1 VS T0 & 4.13 & $2.18-7.81$ & $<0.001$ & 4.33 & $2.36-8.77$ & $<0.001$ \\
\hline 11 VS 10 & 1.25 & $0.64-2.44$ & 0.52 & $\ldots$ & $\ldots \ldots \ldots \ldots$ & $\ldots \ldots \ldots \ldots$ \\
\hline S1 VS S0 & 1.71 & $1.13-2.57$ & 0.01 & 1.69 & $1.12-2.53$ & $<0.01$ \\
\hline Age (yrs) & 0.98 & $0.96-1.00$ & 0.05 & 0.98 & $0.96-1.00$ & 0.01 \\
\hline Nodular KS morphotype & 1.50 & $0.97-2.32$ & 0.07 & 1.34 & $0.84-2.15$ & 0.22 \\
\hline Trunk edema & 2.91 & $1.53-5.53$ & $<0.001$ & 2.45 & $1.27-4.75$ & 0.01 \\
\hline On HAART at diagnosis & 0.75 & $0.54-1.02$ & 0.07 & 0.62 & $0.45-0.87$ & 0.01 \\
\hline Receipt of chemotherapy & 0.46 & $0.33-0.65$ & $<0.001$ & 0.29 & $0.20-0.42$ & $<0.001$ \\
\hline
\end{tabular}

* Multivariate analysis adjusted for T, S, age, nodular morphotype, trunk edema, HAART, and chemotherapy.

* Correspondence: fokuku@fhcrc.org

${ }^{1}$ Uganda Cancer Institute, Kampala, Uganda

Full list of author information is available at the end of the article 
1.7, 95\%CI 1.26-2.39 and $\mathrm{p}=0.001$ ), but ACTG immune status criteria (CD4 under 200 cells/ $\mu$ l) was not.

\section{Conclusions}

ACTG criteria Tumor extent (T) and Systemic symptoms (S) were associated with survival; Immune status (I) was not. Factors associated with decreased survival included: baseline CD4 counts $<100$, age, trunk edema, while receipt of HAART and chemotherapy were associated with increased survival. Studies are needed to validate ACTG staging criteria in sub-Saharan Africa and to identify additional prognostic factors.

\section{Author details}

${ }^{1}$ Uganda Cancer Institute, Kampala, Uganda. ${ }^{2}$ Department of Medicine, Makerere University, College of Health Sciences, Kampala, Uganda. ${ }^{3}$ Department of Medicine, University of Washington, Seattle, WA, USA.

${ }^{4}$ Laboratory Medicine, University of Washington, Seattle, WA, USA. ${ }^{5}$ Epidemiology, University of Washington, Seattle, WA, USA. ${ }^{6} \mathrm{Global}$ Health, University of Washington, Seattle, WA, USA. Vaccine and Infectious Disease Division, Fred Hutchinson Cancer Research Center, Seattle, WA, USA.

Published: 19 April 2012

Cite this article as: Okuku et al.: Evaluation of the AIDS clinical trials group staging criteria for Kaposi Sarcoma in a resource limited setting. Infectious Agents and Cancer 2012 7(Suppl 1):P8.

Submit your next manuscript to BioMed Central and take full advantage of:

- Convenient online submission

- Thorough peer review

- No space constraints or color figure charges

- Immediate publication on acceptance

- Inclusion in PubMed, CAS, Scopus and Google Scholar

- Research which is freely available for redistribution

Submit your manuscript at www.biomedcentral.com/submit 